\title{
正常単球および白血病性単球の 超微形態学的研究
}

北海道大学医学部内科学第三講座

\author{
济藤永仁 \\ 宮 崎保
}

（昭和60年12月12日受付）

\section{はじめに}

一般に, 単球系細胞は著明な非特異的 esterase 活 性を有するが ${ }^{33}$ ，まれに非特異的 esterase 活性の認 められない白血病性単球もある゙。。たがって, 単球 系細胞の同定には, 非特異的 esterase 染色のみなら ず, 種々の細胞化学的検索と表面形質の検索に加えて 電顕的な検索が必要である。単球の超微形態学的特徴 については，これまで多くの報告があるが, 白血病性 単球を系統的に検討した報告は少なく, 現在なお不明 な点が多い。そこで, 正常単球および白血病性単球を 電顕的に観察し, 単球系細胞の超微形態学的特徵につ いて検討を加えた。

\section{材料と方法}

対象となった症例は，昭和55年12月から，昭和 59
年11月までの間に当科に人院した急性単球性 白血病 $\left(\mathrm{AM}_{0} \mathrm{~L}, \mathrm{M}_{5 \mathrm{~b}}\right) 2$ 例, 急性骨髄単球性白血病 $\left(\mathrm{AMM}_{0} \mathrm{~L}\right.$, $\mathrm{M}_{4}$ ) 10 例, 入院時光顕的所見に上り急性骨髄性 白血 病 $\left(\mathrm{AML}, \mathrm{M}_{2}\right)$ と診断されたが, 電䫓的および染色 体検索により，最終的には $\mathrm{AMM}_{0} \mathrm{~L}$ とみなされた 1 例 (表) と正常人 2 例からなる。白血病の細胞学的診 断は, May-Grünwald-Giemsa (MGG) 染色, $\alpha$ naphthyl butyrate esterase (ANBE) 染色々 naphthol AS-D chloroacetate esterase (NASDCAE) 染色を併用した esterase 2 重染色 ${ }^{(4)}$ および peroxidase (PO) 染色 ${ }^{13)}$ によってなされた。一部の 症例には, 2-naphthyl thiol acetate (NTA) を基 質とする esterase 染色 ${ }^{15)}$ も併用した。

走査電顕的観察には, 末梢血採取後, 直ちに $2 \%$ グ ルタールアルデヒド・0.05M カコジル酸緩衝液 $(\mathrm{pH}$ 7.4）に少量の全血を滴下し, $4^{\circ} \mathrm{C}$ で 30 分間固定後,

\begin{tabular}{|c|c|c|c|c|c|c|c|c|c|}
\hline \multirow{2}{*}{ Case } & \multirow{2}{*}{ Sex } & \multirow{2}{*}{ Age } & \multirow{2}{*}{$F A B^{\prime \prime}$} & \multirow{2}{*}{$\begin{array}{l}\text { Percent leukemic } \\
\text { cell(BM) }\end{array}$} & \multicolumn{3}{|c|}{ Cytochemical results of leukemic cells ${ }^{4}$ ? } & \multirow{2}{*}{ Karyotype } & \multirow{2}{*}{$\begin{array}{l}\text { Serum } \\
\text { lysozyme }(\mu / \mu d)\end{array}$} \\
\hline & & & & & non-specific esterase2) & specific esterase ${ }^{3)}$ & peroxidase & & \\
\hline 1 & $F$ & 77 & $M_{5 b}$ & 83 & H & - & \pm & $N D^{51}$ & 450 \\
\hline 2 & $F$ & 46 & $M_{5 b}$ & 94 & H & - & \pm & ND & 472 \\
\hline 3 & $M$ & 50 & $M_{4}$ & 88 & + & + & + & ND & 86 \\
\hline 4 & M & 48 & $\mathrm{M}_{4}$ & 100 & + & + & + & $46 \times Y$ & 102 \\
\hline 5 & $F$ & 54 & $\mathrm{M}_{4}$ & 83 & + & + & \pm & ND & 65 \\
\hline 6 & $M$ & 61 & $M_{4}$ & 60 & + & + & + & ND & 57 \\
\hline 7 & $F$ & 67 & MA & 76 & + & + & + & ND & 204 \\
\hline 8 & $M$ & 37 & $M_{4}$ & 90 & + & + & + & ND & 360 \\
\hline 9 & $F$ & 38 & $M_{4}$ & 57 & + & + & + & $46 \times x$ & 48 \\
\hline 10 & $F$ & 53 & $M_{4}$ & 21 & + & + & + & ND & 64 \\
\hline 11 & $M$ & 53 & $M_{4}$ & 72 & + & + & - & $46 \times Y$ & 31 \\
\hline 12 & $M$ & 52 & $M_{4}$ & 88 & + & + & + & $46 X Y$ & 29 \\
\hline 13 & $M$ & 51 & $M_{2}(?)$ & 55 & - & + & + & $\mid \begin{array}{c}46 \times Y \\
\operatorname{inv16t}(7: 11)\end{array}$ & 10 \\
\hline
\end{tabular}

1) FAB, French-American-British classification 2) non-specific esterase, $\alpha$-naphtyl butyrate esterase

3) specific esterase, naphthol AS-D chloroacetate esterase 4) H; remarkably positive, + ; moderately positive, \pm ; faintly positive, -negative 5) ND, not done 
$2 \% \mathrm{OsO}_{4}$ 水溶液で30分間後固定した。その後, 型の ごとくエタノール系列で脱水し, 酢酸イソアミルで置 換し，臨界点乾燥後，金による真空蒸着を施した。

透過電顕的観察には，未梢血および吸引骨髄片を 2 $\%$ グルタールアルデヒド・ $0.05 \mathrm{M}$ カコジル酸緩衝液 (pH 7.4) で $4{ }^{\circ} \mathrm{C} て ゙ 2$ 時間固定後, $2 \% \mathrm{OsO}_{4}$ 水溶液 で 2 時間後固定し，さらに $1 \%$ 酢酸ウラン水溶液で 12 時間ブロック染色を施した。その後, 型のごとくェタ ノール系列で脱水し，Epon 812 (応研)ないし Spurr (Polysciences) に包埋した。超薄切片はクエン酸鉛 で電子染色を施して，電子顕微鏡で観察した。

なお，細胞質内小器官を立体的に観察する目的で， 厚さ約 $0.5 \sim 1.0 \mu \mathrm{m}$ の厚切切片を作製し, 高生 (200 KV) 下で電顕的に観察した。

また，全例の骨䯣および末梢血の白血病細胞につい て, Daems \& Brederoo の方法 ${ }^{6)}$ に準じて次のよう に電顕的 PO 反応を施行した。試料を $1 \%$ グルタール アルデヒド・0.05 M カコジル酸緩衝液 (pH 7.4) で $4{ }^{\circ} \mathrm{C}, 10$ 分間固定後， $3,3^{\prime}$-diaminobenzidine tetrahydrochloride (DAB) を含む下記の浸漬液に $4^{\circ} \mathrm{C} て ゙$ 30分間浸漬した。

\section{DAB}

0.1 M トリス・塩酸緩衝液 $(\mathrm{pH} 7.6)$

$5 \mathrm{mg}$

$10 \mathrm{ml}$

ついで試料を $0.03 \%$ の過酸化水素を含む DAB 浸漬液 に移し， $37^{\circ} \mathrm{C}$ で 1 時間反応させた後, 蒸留水で速や かに水洗し， $2 \% \mathrm{OsO}_{4}$ 水溶液で 2 時間後固定した。 ついで型のごとく脱水・包埋し, 超薄切片作製後, 無 染色にて電子顕微鏡で観察した。なお，刘照として， 過酸化水素を含まない DAB 浸漬液を用いて同様の反 応を施行した。

\section{成}

\section{績}

検索した全症例の主な細胞化学的所見は表に示し た。一般に光顕的細胞化学では, $\mathrm{AM}_{0} \mathrm{~L}\left(\mathrm{M}_{5 b}\right)$ にお ける白血病細胞は, ANBE 反応は強陽性で, N-ASD$\mathrm{CAE}$ 反応拉よび $\mathrm{PO}$ 反応は大部分の細胞で陰性ない し弱陽性であった。一方， $\mathrm{AMM}_{0} \mathrm{~L}$ 白血病細胞は，ほ とんどの症例で種々な程度に esterase 2 重染色性を 示し，PO 反応も陽性を呈した。しかしながら，症 例11のように, PO 反応が陰性である症例，あるいは 症例13のように, $\alpha$-naphthyl butyrate を基質とす る esterase 反応は陰性で，NTA を基質とした esterase 反応は陽性で，後述するが，電顕的には単球系 の白血病と考兄られた症例もみられた。

単球を走査電顕的に観察すると, 一般に正常単球は ridge が主体の表面構造を有していた。一方，白血病 性単球の表面構造は多様であった。すなわち， $\mathrm{M}_{5 \mathrm{~b}}$ に 扣ける白血病性単球の表面構造は ridge が主体で, ときに ruffle もみられたが， $\mathrm{M}_{4}$ 例では, ridge,

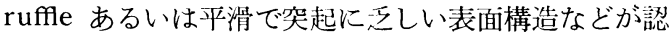
められ，一定の傾向は存在しなかった。なお，正常単 球拈よび白血病性単球の表面には, 径 $0.1 \sim 0.2 \mu \mathrm{m}$ の小孔が散見され，ことに $\mathrm{M}_{5 \mathrm{~b}}$ 例でしばしば観察さ れた（写真 1$)$ 。

透過電顕的観察では，一般に正常人単球の核は著明 な核膜切痕を有し，細胞質は豊富な小器官を有してい た。すなわち，豊富な滑面小胞体，発達したゴルジ装 置, 核膜周縁に高頻度に存在する微細線維束, 被覆小 胞，細胞膜の陥入により形成された多数の空胞などが 認められた。なお，単球の顆粒は一般に小型（径 約 $0.2 \sim 0.5 \mu \mathrm{m})$ で比較的電子密度の高い有芯状構造を 呈しており，しばしば細胞質内で集簇する傾向を示し た（写真 2 )。なお，単球を厚さ約 $0.5 \sim 1.0 \mu \mathrm{m}$ の厚 切切片で高圧下に観察すると，かかる集簇した小型の 顆粒は複雑に弯曲・蛇行した短径約 $0.25 \mu \mathrm{m}$ ，長 径 $0.5 \sim 2.0 \mu \mathrm{m}$ の短〜長桿状顆粒の集団の断面像 と考 えられた。

一方, 白血病性単球は基本的に正常単球と注汇同様 の特徵を呈していたが（写真 3 ), しばしば著明な核 小体や nuclear pocket を有し，正常単球に比較して 形態学的に異型性が認められた。ときに, B-body ${ }^{26)}$, labyrinth-like structure ${ }^{4)}$, compound endoplasmic reticulum $^{5)}$ (paired cisternae) ${ }^{29)}$, annulate lamel$\mathrm{la}^{31)}$ なども認められた（写真 4 )。 $\mathrm{M}_{5 b}$ の白血病性単 球は, $\mathrm{M}_{4}$ の白血病性単球に比べて, 単球的特徵が著 明であったが，基本的には両者は共通した単球の超微 形態学的特徵を備えていた。なお，白血病性単球にお いてもしばしば正常単球と同様の集簇した小型の顆粒 が観察された。厚切切片で観察すると，かかる集簇し た顆粒は，正常単球と同様に，複雑に弯曲・蛇行した 短〜長桿状顆粒の集団として観察された。かかる集簇 した顆粒は PO 反応陽性であった。一方, 細胞質内に 散在する小型の有芯状顆粒も $\mathrm{PO}$ 活性を有し, これら は細胞膜辺縁付近に存在する傾向を示した。ことに， その傾向は $\mathrm{M}_{5 \mathrm{~b}}$ 例で顕著であった（写真 5 )。

今回検索した大部分の $\mathrm{M}_{4}$ 症例において，その白血 病細胞は電顕的 $\mathrm{PO}$ 反応执よび非特異的 esterase 反 怂陽性であったが，症例11では白血病細胞は電顕的 PO 反応陰性, 症例13では ANBE 反応は陰性で, 他 の $\mathrm{M}_{4}$ 症例とは明らかに異なっていた。しかしなが 
ら, 症例11, 症例13の白血病細胞を透過電顕的に検索 すると, 核は核膜切痕を有し, 細胞質には微 細 線 維 束, 被覆小胞, 豊富な滑面小胞体, 細胞膜の陥入によ り形成された空胞, 単球特有の小型の有芯状顆粒およ び集簇顆粒が認められ，明らかに単球の特徵を有して いた。したがって, 症例11および症例13はいずれも $\mathrm{AMM}_{0} \mathrm{~L}$ と考えられた（写真 6 )。なお，症例 13 で は，第16番染色体の逆位も認められた。

\section{考察}

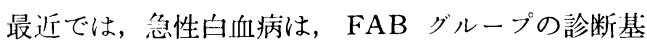

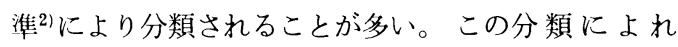
ば, 単球系白血病 $\left(M_{4}, M_{5}\right)$ の診断には, Romanowsky 染色あるいは MGG 染色に加えて, 非特異的 esterase 染色およびPO 染色の所見が参考にされて いる。一般に $\mathrm{M}_{5}$ では白血病細胞は非特異的 esterase 染色が強陽性を呈し, 診断は比較的容易である。一 方, $\mathrm{M}_{4}$ では非特異的 esterase 染色陽性の細胞と, 特異的 esterase 染色ないし PO 染色陽性細胞からな り, しばしば esterase 2 重染色性を有する細胞も存 在する ${ }^{28)}$ 。しかしながら, まれに白血病細胞が非特異 的 esterase 活性を示さない $\mathrm{AMMoL}$ 症例も報告さ れている3)。症例13の白血病細胞では非特異的 esterase 染色は陰性であったが, 電顕的には白血病細 胞は前述の単球の特徵を備えており, しか子第 16 番染 色体の逆位も認められたことから, 非特異的 esterase 染色陰性の $\mathrm{AMM}_{0} \mathrm{~L}$ と考劣られた。第16番染色 体の逆位については, Le Beau ら ${ }^{16)}$ は $\mathrm{M}_{4}$ に特有の 異常であると最近報告しており, 症例13が $\mathrm{AMM}_{0} \mathrm{~L}$ であることが染色体検索の結果からも裏付けられた。

単球の超微形態学的特徵としては, 一般に, 著明な 核膜切痕, 発達したゴルジ装置, 微細線維束, 豊富な 滑面小胞体, 被覆小胞, 小型の有芯状顆粒および細胞 膜の陷入によって形成された空胞などがあげられるい 11)19)。微細線維束は一般に単球系細胞でしばしば観察 されるが, 単球系細胞以外の種々の白血病細胞に打い ても認められ ${ }^{8 / 27)}$, 細胞の運動, 細胞内小器官の移動 および支持と関係がある構造物と考えられている ${ }^{12) 。 ~}$ かかる微細線維束は, 核の周縁の細胞質内に多く分布 $\mathrm{j}$ するが7, 本研究においても, 核の周緑に認められ, とくに $\mathrm{M}_{5 \mathrm{~b}}$ 例で高頻度に観察された。なお, 通常の 超薄切片を用いて単球を電顕的に観察すると, 顆粒は 一般に小型で, 有芯状の円型ないし短桿状形態を呈 し，集簇する傾向を示す ${ }^{32)}$ 。かかる集簇した顆粒の存 在について, Nichols ら ${ }^{18)}$ は, ウサギの単球において
その存在を指摘している。今回観察した全症例におい ても，正常あるいは白血病を問わず単球は集簇した小 型の顆粒を有していた。電顕的に高生下で厚切切片を 観察すると, かかる集簇した顆粒は, 複雑に弯曲・蛇 行した短〜長桿状の顆粒集団の断面像であることが判 明した。

一般に単球に認められる顆粒は, PO 活性とリゾチ 一ム活性を有する。後者は単球の顆粒に高濃度に含ま れ24), 種々の条件下で細胞外へ放出されることが知ら れている ${ }^{10)}$ 。本研究においてもPO 陽性顆粒が細胞質 辺縁部に高頻度に認められ，ときには顆粒が細胞外に 放出されつつあるかのごとき像も認められ，しかもそ の傾问がリゾチーム高值の $\mathrm{M}_{5 \mathrm{~b}}$ 例に著明に認められ た。この事実は, PO 陽性顆粒がライソジームとして 練胞内から血中に放出されることによって血清リゾチ 一ム值が上昇することを示唆した形態学的所見かもし れない。なお，小型の集簇した顆粒，および顆粒の細 胞質辺縁部における局在傾向は単球に特有の所見々考 えられた。

白血病性単球において垫められた B-body は, virus との異同が問題とされたこともあるが26), 現在な お，その意義は不明である。最近，かかる構造物に acid phosphatase 活性が認められており ${ }^{251}$ ，ライソ ゾームの可能性が示唆されている。Labyrinth-like structure ${ }^{4)}$ は細胞膜の異常な陥入によって形成され た構造で, 単球・マクロファージ系細胞にしばしば認 められる。Compound endoplasmic reticulum (paired cisternae $)^{5)}$ は隣接した一対の粗面小胞体からな るが，ある種の virus 感染で出現する構造物之考兄 られており ${ }^{29)}$, 病態と何らかの関係があるかもしれな い。Annulate lamellae は增殖の激しい細胞に出現 すると考えられているが，その正確な機能的意義は不 明である。これらの構造は, labyrinth-like structure は別として, 種々な白血病細胞にも璆められ, 白血病 性単球に特有の構造とは考兄られない。しかしなが ら, かかる構造は白血病の発症・進展と何らかの関連 性がある可能性もあり，今後の恰討が必要であろう。

なお，細胞化学的には $M_{4}$ と $M_{5}$ では esterase 2 重染色の染色性が異なり両者はあきらかに区別され得 る17)。しかしながら電顕的検索では， $\mathrm{M}_{5 \mathrm{~b}}$ の白血病細 胞においては単球的特徵が著明であり， $\mathrm{M}_{4}$ の白血病 細胞も基本的には典型的単球の特徵を備えていた。し かも, esterase 2 重染色性を示す白血病細胞（細胞化 学的には顆粒球と単球の両性格を有している細胞）も あきらかな単球の超微形態学的特徽を有しており電顕 
的所見と細胞化学的所見の解離が存在する ${ }^{23)}$ 。かかる 解離については, 白血病細胞の分化の多様性が強く関 連していると考えられ，今後さらに検討すべき問題と いえよう。

正常単球および $M_{5 b}$ における白血病性単球の表面 構造については, ruffle が特徴的構造であると報告さ れてきたが9(20) 22) 301，今回の観察では，正常単球およ び $\mathrm{M}_{5 \mathrm{~b}}$ 症例の白血病性単球の表面構造はむしろ ridge が主体であり，従来の報告とは合致しない。この点に 関しては，さらに症例を集積して検討したい。なお， 単球采細胞の表面には, しばしば小孔が認められた が，かかる構造は，マクロファージにおいて指摘され ており ${ }^{21)}$, 単球・マクロファージ系細胞に特有の表面 構造であることが考えられる。

$$
\text { 結語 }
$$

正常人単球と, $\mathrm{AMM}_{0} \mathrm{~L}$ および $\mathrm{AM}_{0} \mathrm{~L}$ における白 血病性単球の超微形態学的特徵について検討した。

1）透過電䫓的に正常人単球を観察すると, 著明な核 膜切痕, 発達したゴルジ装置, 豊富な滑面小胞体, 微 細線維束, 被覆小胞, 細胞膜の陥入により形成された 空胞, 小型の有芯状顆粒および集簇顆粒などが認めら れた。なお，集簇顆粒を厚切切片で立体的に観察する

\section{文}

1) Anderson, D. R.: Ultrastructure of normal and leukemic leukocytes in human peripheral blood. J. Ultrastruct. Res. (Supplement 9). pp5-42, Acad. Press, New York-London, 1966.

2) Bennet, J. M., Catovsky, D., Daniel, M. T., Flandrin, G., Galton, D. A. G., Gralnick, H. R. \& Sultan, C. : Proposals for the classifica tion of the acute leukaemias. Br. J. Haematol., 33 : 451-458, 1976.

3) Bitter, M. A., Le Beau, M. M., Larson, R. A. Rosner, M. C., Golomb, H. M., Rowley, J. D. \& Vardiman, J. W.: A morphologic and cytochemical study of acute myelomonocytic leukemia with abnormal marrow eosinophils associated with inv (16) (p 13q22). Am. J. Clin. Pathol., 81 : 733-741, 1984.

4) Brederoo, P. \& Daems, W. Th.: Cell coat, worm-like structures, and labyrinths in guinea pig resident and exudate peritoneal macrophages, as demonstrated by an abbreviated fixa-
と, 弯曲・蛇行した桿状顆粒の集団からなり，単球に 特有な構造と考えられた。

2）一方，白血病性単球も基本的に正常人単球と共通 の特徴を備えていたが，一般に異型性が強く，しばし ば著明な核小体, nuclear pocket が認められ，とき には正常人単球には存在しない B-body, compound endoplasmic reticulum (paired cisternae), annulate lamellae なども認められた。

3）単球の顆粒は電顕的 PO 陽性であった。なお，血 清リゾチームが高值を示した症例における白血病性単 球では, PO 陽性顆粒は細胞質辺縁部で密に分布する 傾向を示した。

4）走査電顕による観察では，正常人の単球の表面は ridge 様構造を呈したが，白血病性単球では表 面構 造は多様であった。なお，正常および白血病性単球の 表面には, しばしば小孔が認められた。

稿を終るにあたり，御愍切な御指導御校閲を賜わり ました北海道大学第 3 内科学講座宮崎保教授および竹 森信男講師に深甚の謝意を表します。

本論文の要旨は，第10回国際網内系学会において発 表した。

\section{献}

tion procedure for electron microscopy. Z. Zellforsch., $126: 135-156,1972$.

5) Chandra, S. \& Stefani, S. S.: A possible mode of formation of tubuloreticular structures. J. Ultrastruct. Res., $56:$ 304-311, 1976.

6) Daems, W. Th. \& Brederoo, P.: Electron microscopical studies on the structure, phagocytic properties, and peroxidatic activity of resident and exudate peritoneal macrophages in the guinea pig. Z. Zellforsch., $144: 247-297$, 1973.

7) De Petris, S., Karlsbad, G. \& Pernis, B. : Filamentous structures in the cytoplasm of normal mononuclear phagocytes. J. Ultrastruct. Res., $7: 39-55,1962$.

8) Freeman, J. A. \& Samuels, M. S.: The ultrastructure of a "Fibrillar Formation" of leukemic human blood. Blood, $13: 725-731$, 1958.

9) Hattori, A. : b. Scanning electron microscopy 
of human peripheral blood cells. Acta Haematol. Jpn., $35: 457-482,1972$.

10) Henson, P.M.: Pathologic mechanisms in neutrophil-mediated injury. Am. J. Pathol., 68 : 593-612, 1972.

11) Hirsch, J. G. \& Fedorko, M. E.: Ultrastructure of humen leukocytes after simultaneous fixation with glutaraldehyde and osmium tetroxide and "postfixation" in uranyl acetate. J. Cell Biol., 38 : 615-627, 1968.

12）石川春律：細胞運動とマイクロフィラメント。電 子顕徽鏡, $14: 102-110,1980$.

13) Kaplow, L. S. : Simplified myeloperoxidase stain using benzidine dihydrochloride. Blood, 26 : 215-219, 1965.

14) Kass, L. \& Peters, C. L. : Esterases in acute leukemias. A cytochemical and electrophoretic study. Am. J. Clin. Pathol., 69 : 57-61, 1978.

15) Kim, H., Pangalis, G. A., Payne, B. C., Kadin, M. E. \& Rappaport, H.: Ultrastructural identification of neoplastic histiocytesmonocytes. An application of a newly developed cytochemical technique. Am. J. Pathol., 106 : 204-223, 1982.

16) Le Beau, M.M., Larson, R. A., Bitter, M. A., Vardiman, J. W., Golomb, H. M. \& Rowley, J. D. : Association of an inversion of chromosome 16 with abnormal marrow eosinophils in acute myelomonocytic leukemia. A unique cytogenetic-clinicopathological association. N. Engl. J. Med., 309 : 630-636, 1983.

17）宮㟝 保, 竹森信男, 斉藤永仁: Myelomonocytic and monocytic leukemia の臨床とその白血病細 胞の細胞化学ならびに超微形態学からみた特徵。マ クロファージとその周辺, pp 43-65, 羊土社, 東 京, 1985.

18) Nichols, B. A., Bainton, D. F. \& Farquhar, M. G. : Differentiation of monocytes. Origin. nature, and fate of their azurophil granules. J. Cell Biol., 50 : 498-515, 1971.

19) Nichols, B. A. \& Bainton, D. F. : Differentiation of human monocytes in bone marrow and blood. Sequential formation of two granule populations. Lab. Invest., 29 : 27-40, 1973.

20) Polliack, A. : Scanning electron microscopy and the surface morphology of human leukocytes: Current status. Israel J. Med. Sci., 15 : 629-638, 1979.

21) Polliack, A. \& Gordon, S. : Scanning electron microscopy of murine macrophages. Surface characteristics during maturation, activation, and phagocytosis. Lab. Invest., $33: 469-477$, 1975.

22) Polliack, A., McKenzie S., Gee, T., Lampen, N., de Harven, E. \& Clarkson, B. D. : A scanning electron microscopic study of 34 cases of acute granulocytic, myelomonocytic, monoblastic and histiocytic leukemia. Am. J. Med., 59 : 308315, 1975.

23）斉藤永仁, 竹森信男, 立花法子, 彭 文杰, 今村 雅寛, 武蔵 学, 森岡正信, 桶口晶文, 桜田恵右, 宮崎 保, 山口秀昭：白血病性単球の超微形態一非 特異的・特異的 esterase 活性との比較。第26回日 本臨床血液総会演説抄録, pp 262, 名古屋, 1984 .

24）斉藤永仁, 竹森信男, 立花法子, 彭 文杰, 桜田 恵右, 宮㟝 保: Immunogold staining (IGS) 法 による血液細胞内リゾチームの局在の検討。医学の あゆみ, $135: 69-70,1985$.

25）斉藤永仁, 竹森信男, 立花法子, 彭 文杰, 武蔵 学, 森岡正信, 桜田恵石, 宮㟝保, 山口秀昭： 白血病細胞質内に認められた小胞複合体構造一光顕 - 電顕的観察—。（準備中）

26) Seman, G. : Ultrastructural study of B-bodies in leukapheresed cells of patients with acute leukemia. Oncology, 38 : 204-209, 1981.

27) Shamoto, M., Murakami, S. \& Zenke, T.: Adult T-cell leukemia in Japan. An ultrastructural study. Cancer, 47 : 1804-1811, 1981.

28) Tavassoli, M., Shaklai, M. \& Crosby, W. H. : Cytochemical diagnosis of acute myelomonocytic leukemia. Am. J. Clin. Pathol., 72 : 59$62,1979$.

29) Tooze, J., Tooze, S. A. \& Warren, G. : Laminated cisternae of the rough endoplasmic reticulum induced by coronavirus MHV-A 59 infection. Eur. J. Cell Biol. 36 : 108-115, 1985.

30) Tsukada, M., Komiyama, A., Yoshie, H., Yoda, S., Hara, T. \& Akabane, T.: Differentiation of monocytes in vitro as demonstrated by scanning electron microscopy: Cell defects 
in childhood acute leukemia. Acta Haematol. Jpn., $46: 100-105,1982$.

31) Verwilghen, R. L., Broeckaert-Van Orshoven, A. \& Heynen, M. J.: Dyserythropoiesis and annulate lamellae. Br. J. Haematol., $30: 307-$ 312, 1975.

32) Watanabe, I., Donahue, S. \& Hoggatt N. : Method for electron microscopic studies of cir- culating human leukocytes and observations on their fine structure. J. Ultrastruct. Res. 20 : 366-382, 1967.

33) Yam, L. T., Li, C. Y. \& Crosby, W. H.: Cytochemical identification of monocytes and granulocytes. Am. J. Clin. Pathol. $55: 283-$ 290, 1971.

\section{写 真 説 明}

1. a ) 正常単球：表面構造は ridge が主体で小孔（矢印）が散在している。( $\times 24,000)$

b) 白血病性単球（case 1, $\mathrm{M}_{5 \mathrm{~b}}$ ) : 表面構造は ridge を呈する。 $(\times 6,000)$

c）白血病性単球（case 1): 細胞表面に小孔（矢印）が認められる。 $(\times 20,000)$

d) 白血病性単球 (case $\left.9, M_{4}\right)$ : 細胞表面に ruffle (矢印) が認められる。 $(\times 8,000)$

e) 白血病性単球 (case 7, $\left.\mathrm{M}_{4}\right)$ : 表面構造は ridge を呈する。 $(\times 8,000)$

f) 白血病性単球 (case $\left.4, \mathrm{M}_{4}\right)$ : 細胞表面は平滑である。 $(\times 8,000)$

2. a ) 正常単球 : 著明な核膜切痕と豊富な細胞質内小器官が特徵である。細胞膜の陥入により形成された空胞 （矢印）を認める。 $(\times 9,600)$

b ) 2. a ) の拡大像 : 核膜周縁の微細細維束（矢印）である。 $(\times 24,000)$

c ） 2. a ) の拡大像：鋰粒は小型で，集簇している (矢印)。( $\times 18,000)$

d) 正常単球厚切切片：顆粒は長桿状で, 複雑に弯曲・蛇行し, 集簇している。( $\times 18,000)$

3. a ) 白血病性単球（case 8, $\mathbf{M}_{4}$ ) : 核膜切痕は著明で, 細胞質内には, 豊富な滑面小胞体と細胞膜の陥入に より形成された多数の空胞, 核膜周縁の微細線維束が認められる。小型の複雑に弯曲・蛇行した長桿状顆 粒が集簇している (矢印)。( $\times 7,200)$

b ) 3. a ) の拡大像 : 小型の長桿状顆粒の集団である。( $\times 30,000)$

c) 白血病性単球 (case 2, $\mathrm{M}_{5 \mathrm{~b}}$ ) : 核膜切痕は著明で, 細胞質内には豊富な滑面小胞体と細胞膜の陥入によ る空胞, 核膜周縁の微細線維束が認められる。小型の複雑に弯曲・蛇行した長桿状顆䊀が集簇している (矢印)。( $\times 12,000)$

d） 3. c ) の拡大像 : 小型の長桿状顆粒の集団である。( $\times 30,000)$

4. a) 白血病性単球にみられた B-body (case 4)：やや電子密度の高い内容物を有し, 網様管状複合体構造 を呈する。( $\times 36,000)$

b ）白血病性単球にみられた labyrinth-like structure（case 1)：細胞膜の陥入による迷路状構造である。 $(\times 36,000)$

c) 白血病性単球にみられた compound endoplasmic reticulum (case 8): 隣接した粗面小胞体で構成 される (矢印)。( $\times 24,000)$

d) 白血病性単球にみられた annulate lamelllae (case 5)（矢印)。( $(\times 24,000)$

5. a) 白血病性単球厚切切片 (case 1): 正常単球と同様に夥粒は複雑に弯曲・蛇行し, 集簇している（矢 印)。著明な核膜切痕, 細胞膜の陥入により形成された空胞が認められる。 $(\times 9,600)$

b) 白血病性単球厚切切片 (case 1): 鋰粒は複雑に弯曲・蛇行し, 集簇している。 $(\times 30,000)$

c) 白血病性単球の PO 反応 (case 8)：集簇した小型の楼粒は PO 反応陽性を呈する。 $(\times 7,000)$

d ） 白血病性単球の PO 反応 (case 2)：PO 反応陽性の顆粒が細胞質辺縁に局在する。 $(\times 9,600)$

e ）白血病珄単球の PO 反応 (case 2)：PO陽性颗粒の細胞外への放出過程がうかがえる。 $(\times 30,000)$

6. a) 白血病性単球 (case 11)：本例の白血病細胞は電顕的 PO 反応陰性であったが光顕的に esterase 2 重 染色性が認められた。核膜切痕, 滑面小胞体, 細胞膜の陥入による空胞形成, 小型の集簇した顆粒が認め られ，電䫓的に単球の特徵を備えている。 $(\times 32,000)$ 
b ) 白血病性単球 (Case 13, $\mathrm{M}_{2}$ ) : 本例の白血病細胞は光顕的に非特異的 esterase 反応が陰性で, FAB 分類では $\mathrm{M}_{2}$ と考えられた。電顕的には白血病細胞は著明な核膜切痕, 豊富な滑面小胞体, 細胞膜の陥入 により形成された空胞, 単球に特徵的な小型の集簇した顆粒（矢印）が認められ, 単球系細胞とみなされ た。 $(\times 32,000)$ 
日本網内系学会会誌

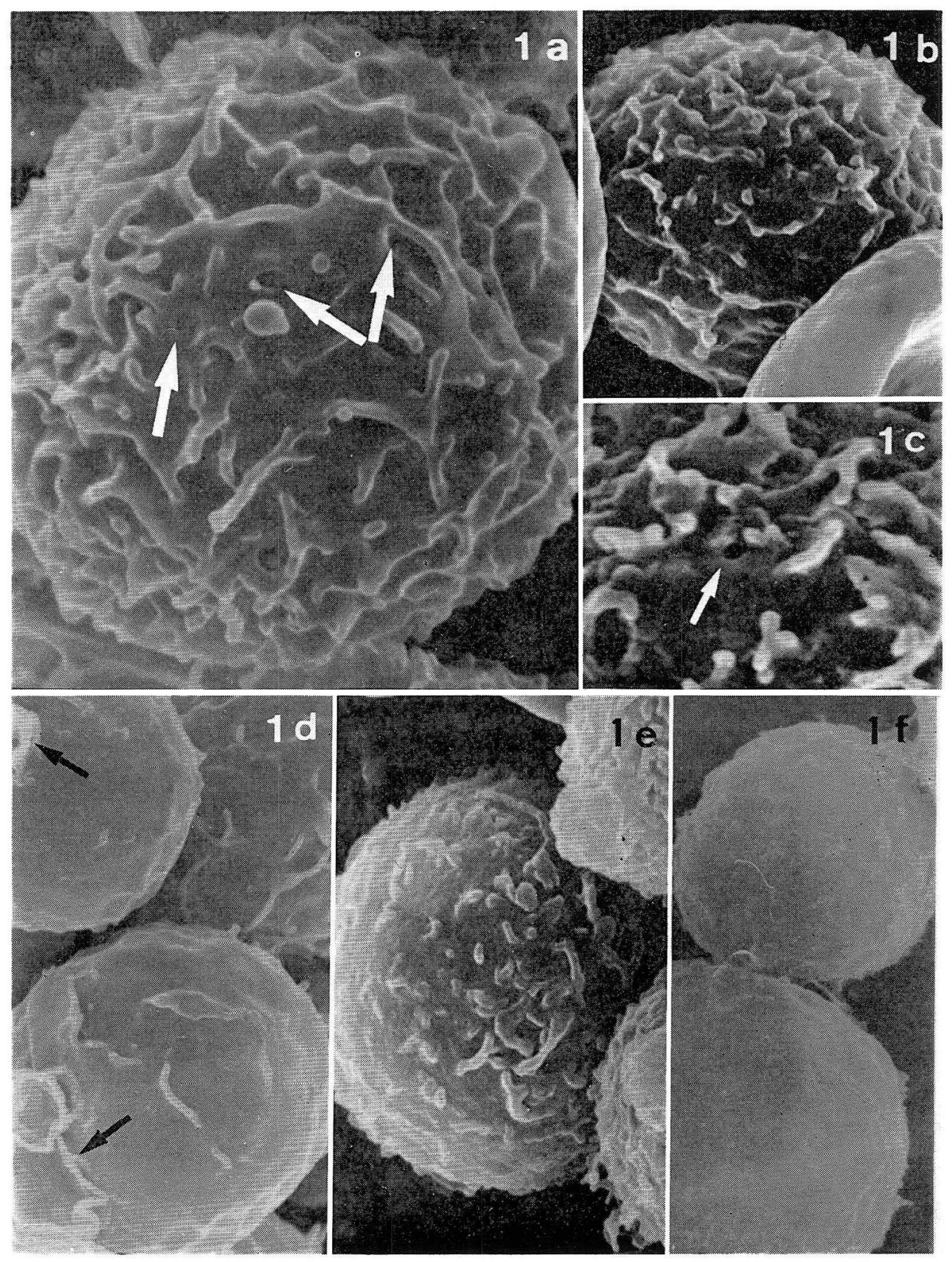




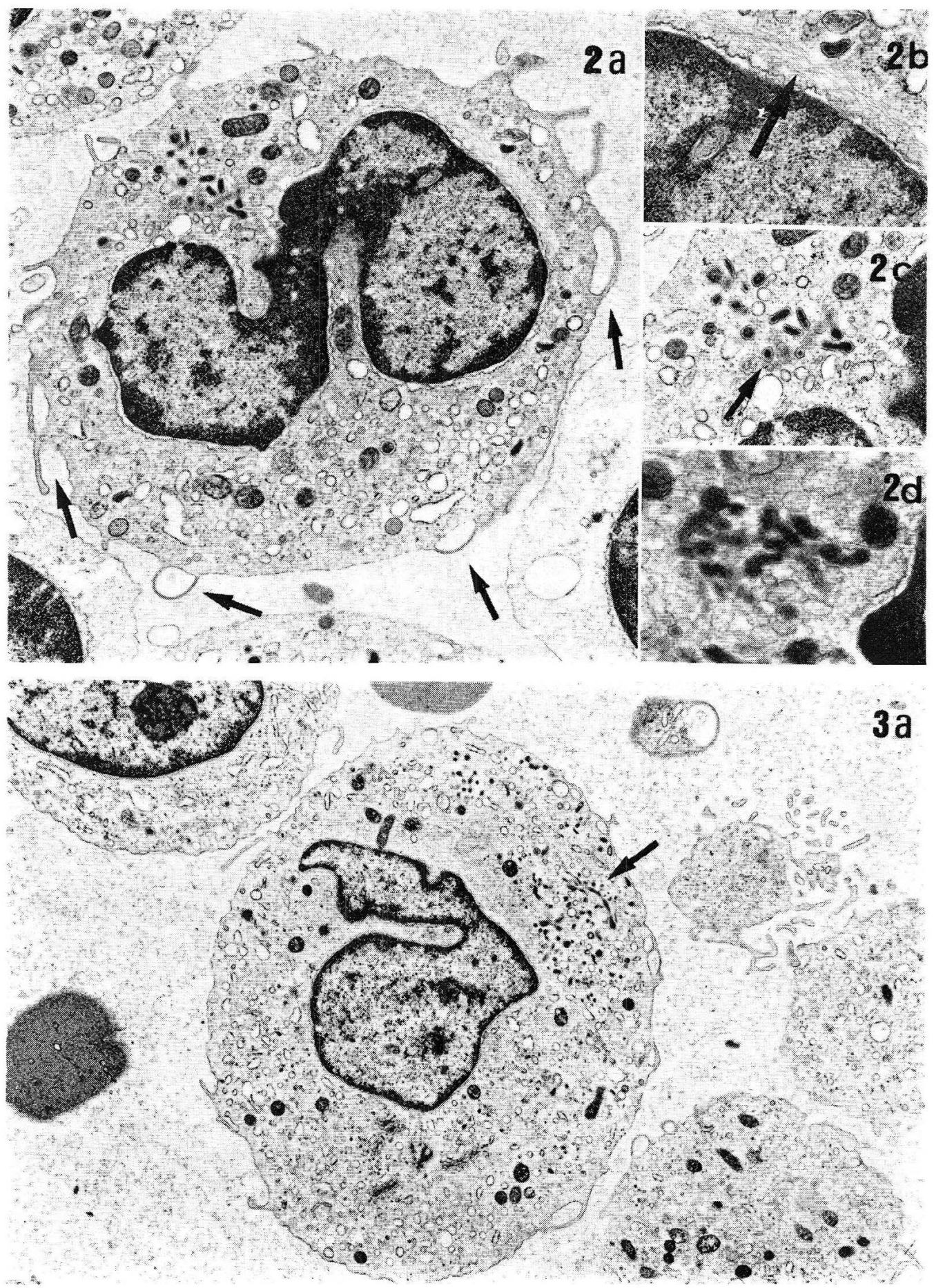



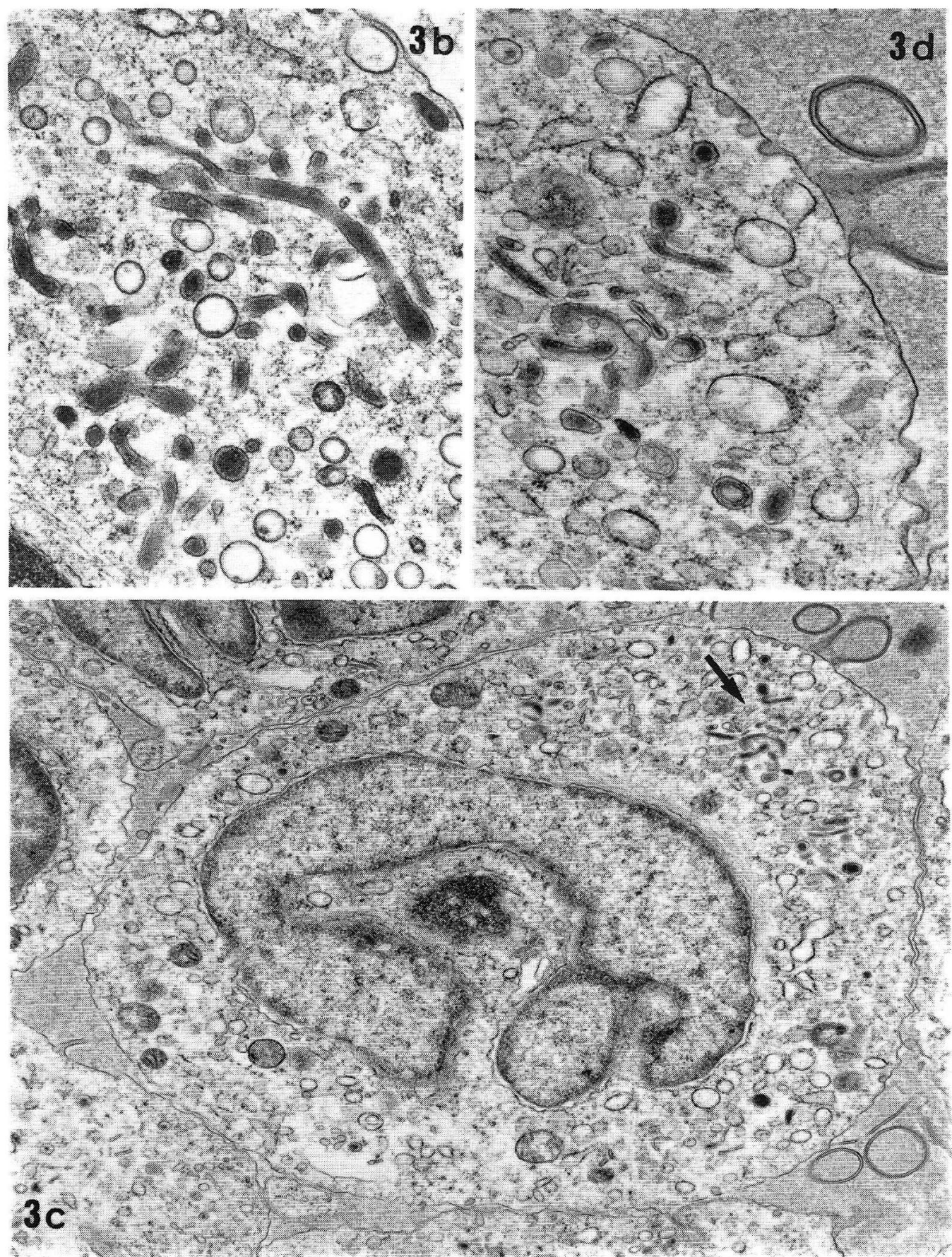


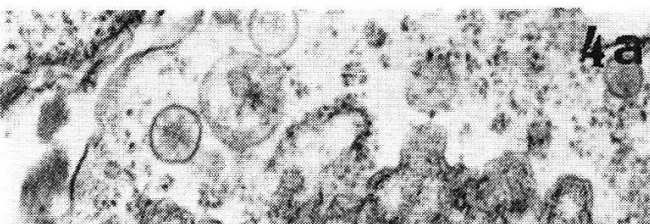

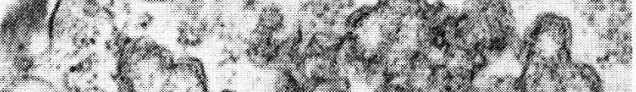

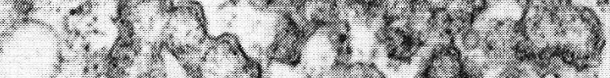

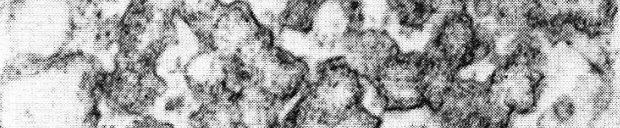

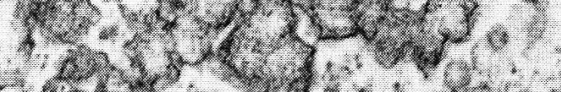

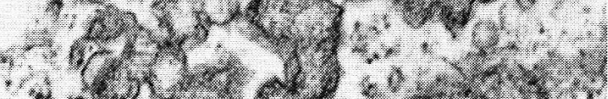

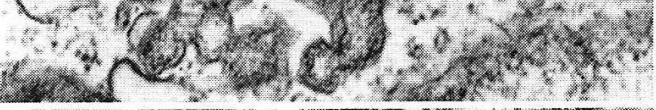
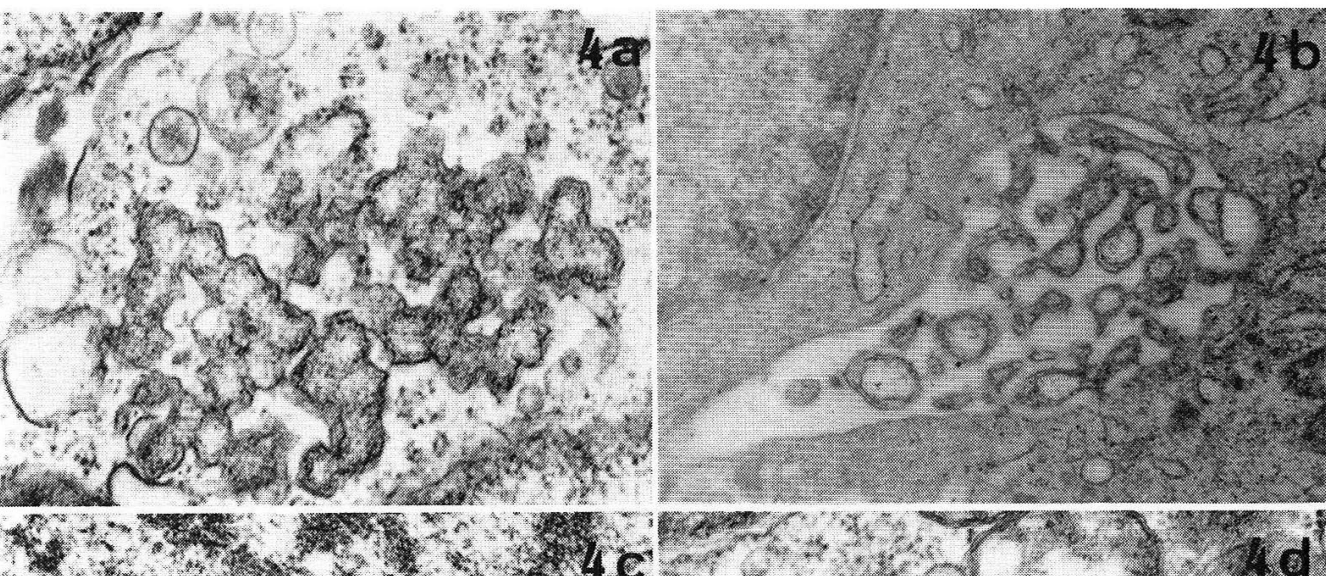

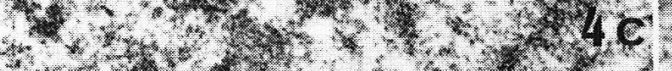

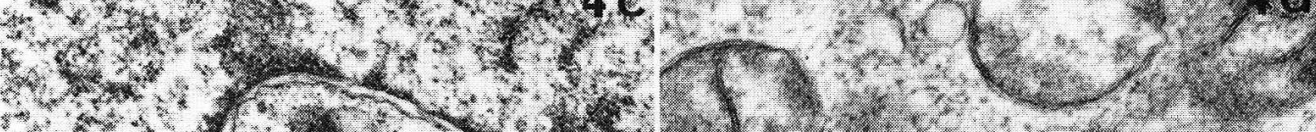

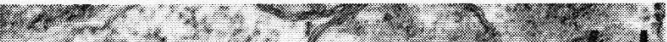

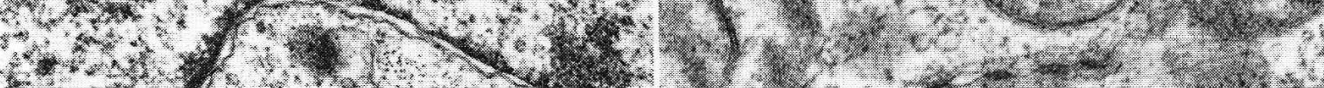

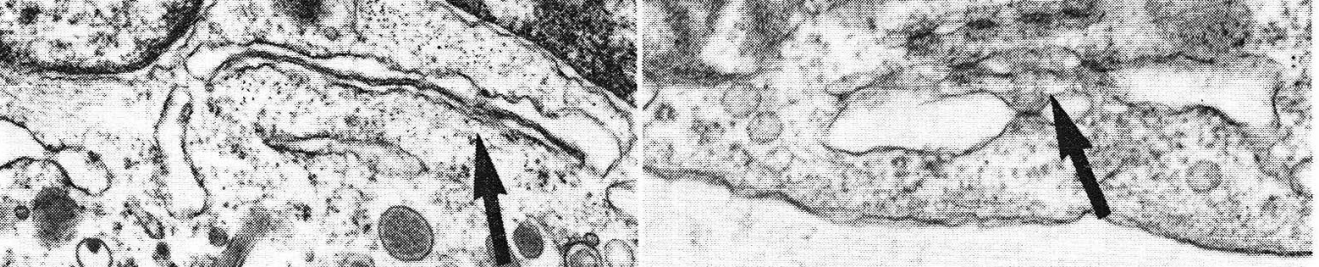

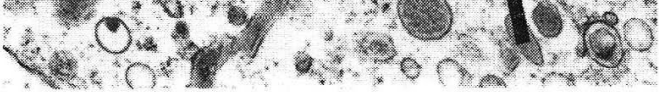
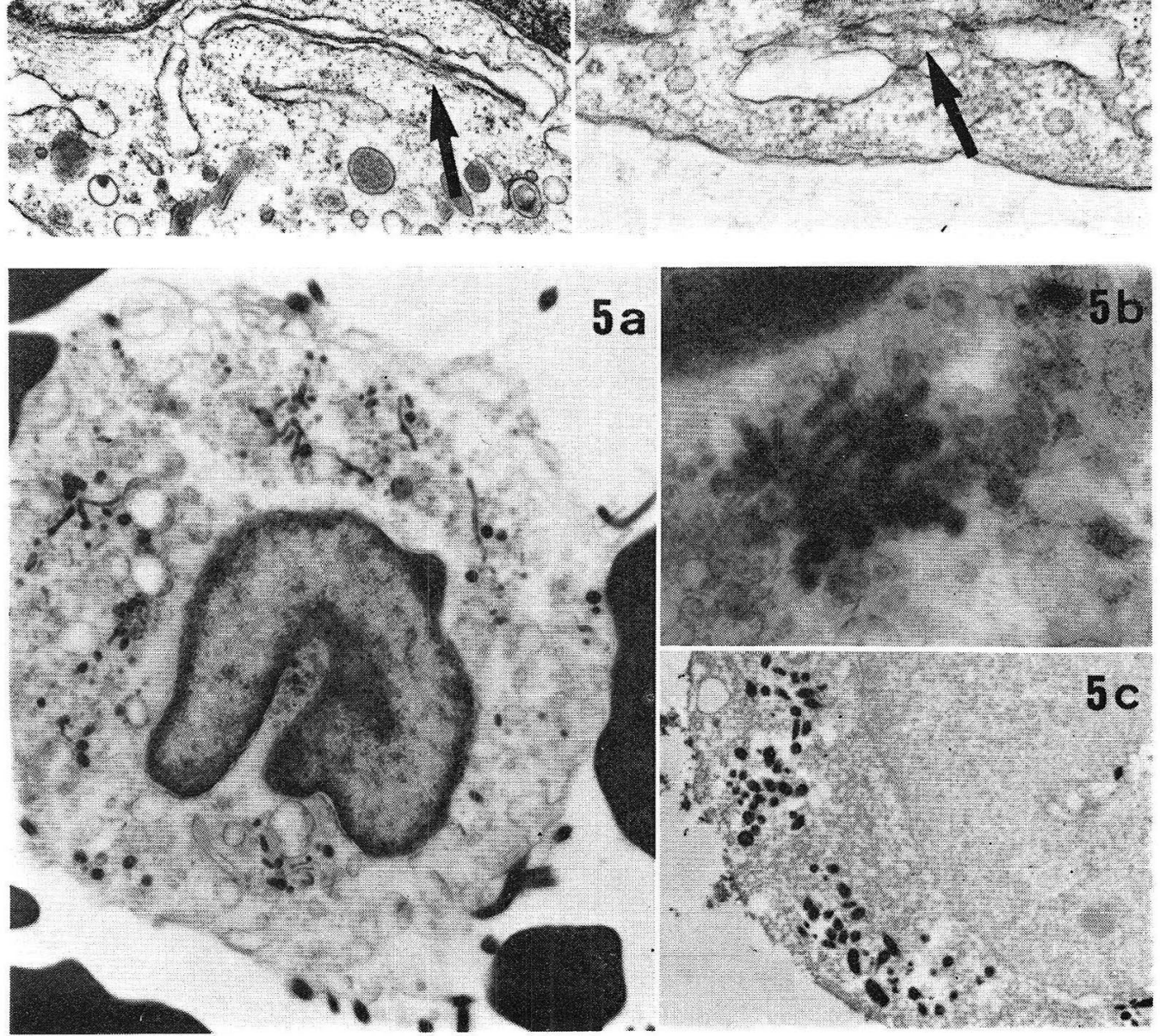

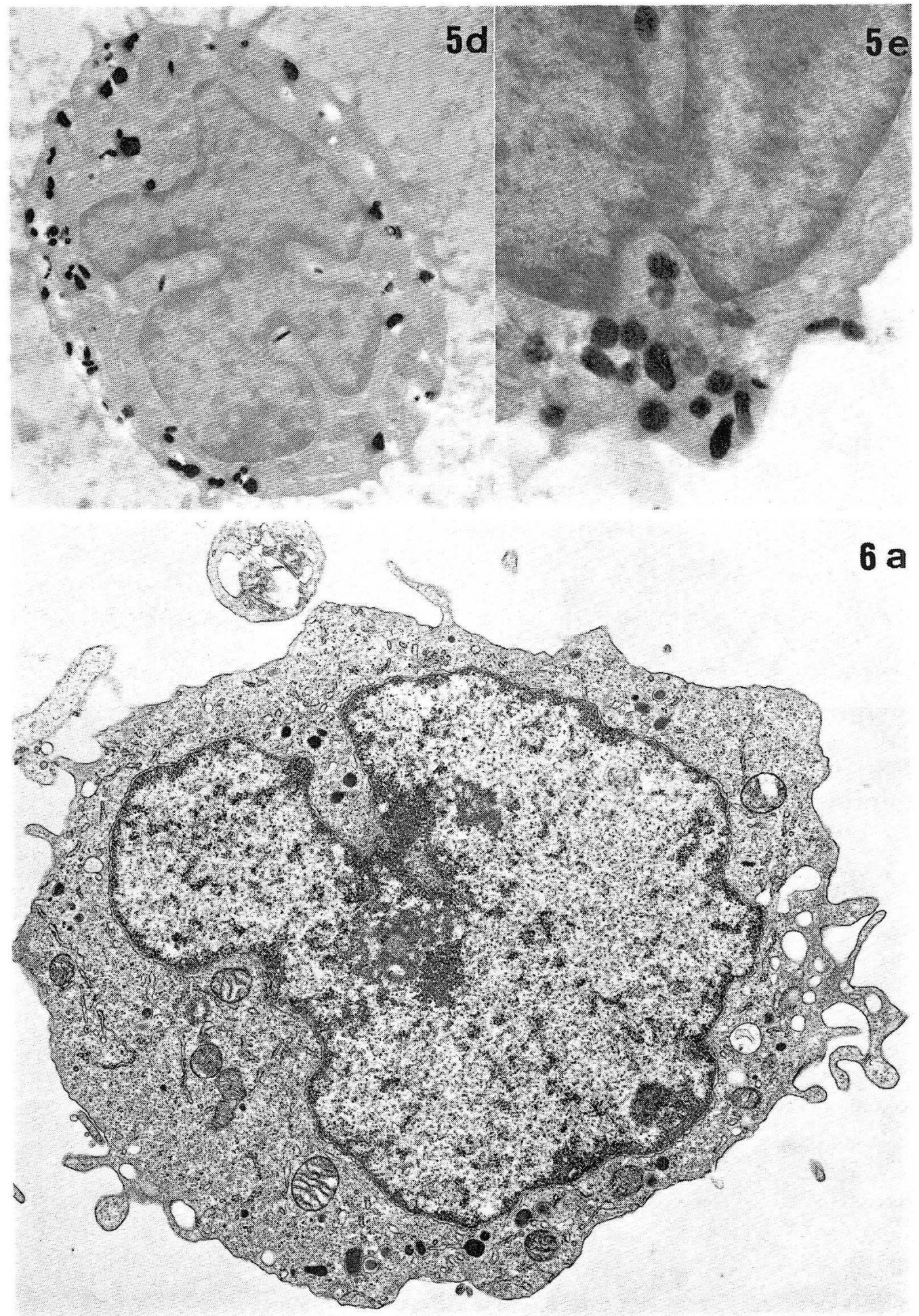


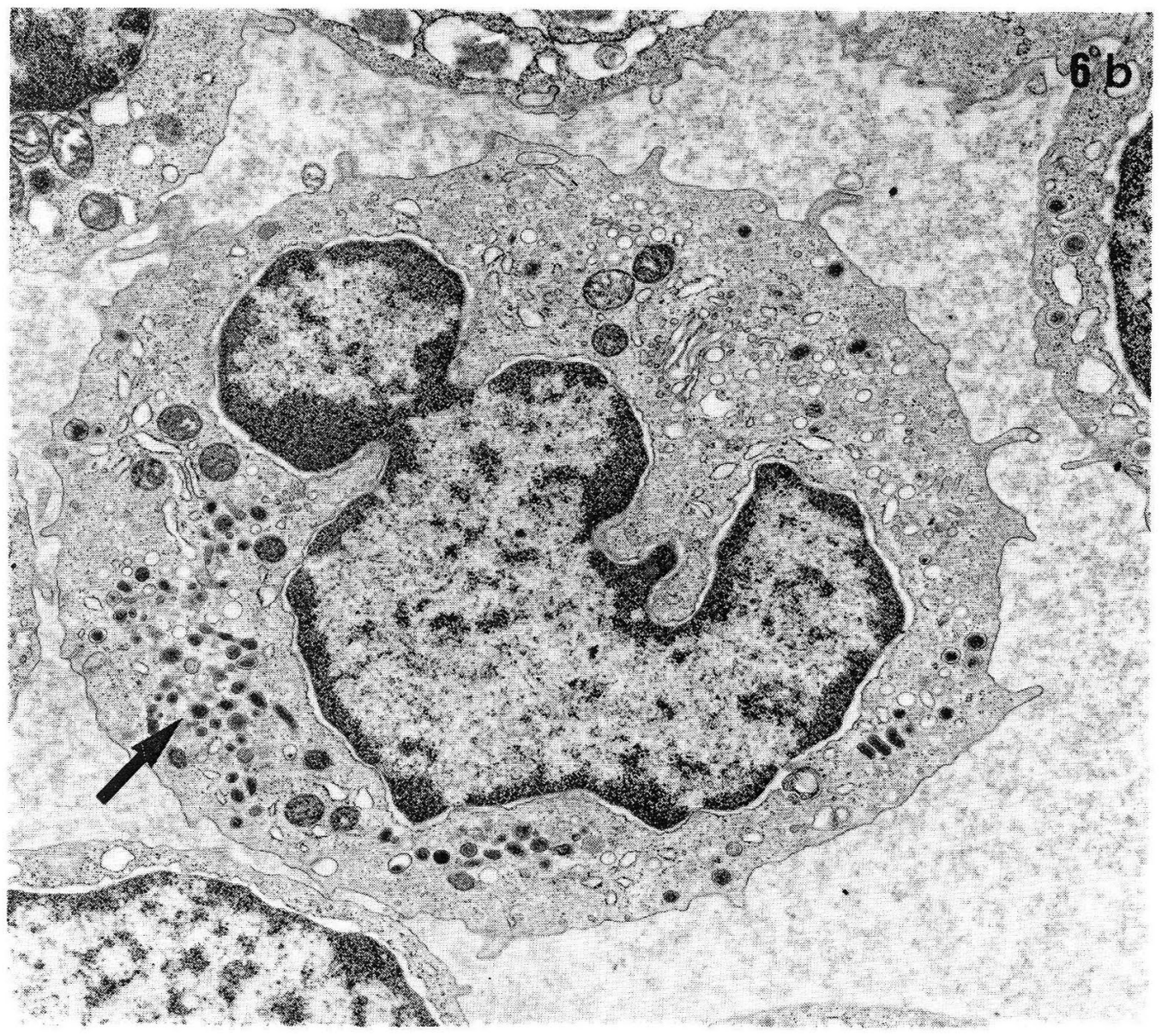

